OPEN ACCESS

Edited by:

John D. Lambris,

University of Pennsylvania,

United States

Reviewed by:

Maria-Grazia De Simoni, Istituto Di Ricerche Farmacologiche

Mario Negri, Italy

Marcela Pekna

University of Gothenburg, Sweden

*Correspondence:

E. Sander Connolly Jr. esc5@columbia.edu

Specialty section

This article was submitted to Molecular Innate Immunity, a section of the journal

Frontiers in Immunology

Received: 16 May 2019

Accepted: 09 July 2019

Published: 30 July 2019

Citation:

Clarke AR, Christophe BR, Khahera A

Sim JL and Connolly ES Jr (2019)

Therapeutic Modulation of the Complement Cascade in Stroke.

Front. Immunol. 10:1723.

doi: 10.3389/fimmu.2019.01723

\section{Therapeutic Modulation of the Complement Cascade in Stroke}

\author{
Alison R. Clarke, Brandon R. Christophe, Anadjeet Khahera, Justin L. Sim and \\ E. Sander Connolly Jr.* \\ Cerebrovascular Research Laboratory, Department of Neurological Surgery, Columbia University Irving Medical Center, \\ New York, NY, United States
}

Stroke is a leading cause of death and disability worldwide and an increasing number of ischemic stroke patients are undergoing pharmacological and mechanical reperfusion. Both human and experimental models of reperfused ischemic stroke have implicated the complement cascade in secondary tissue injury. Most data point to the lectin and alternative pathways as key to activation, and C3a and C5a binding of their receptors as critical effectors of injury. During periods of thrombolysis use to treat stroke, acute experimental complement cascade blockade has been found to rescue tissue and improves functional outcome. Blockade of the complement cascade during the period of tissue reorganization, repair, and recovery is by contrast not helpful and in fact is likely to be deleterious with emerging data suggesting downstream upregulation of the cascade might even facilitate recovery. Successful clinical translation will require the right clinical setting and pharmacologic strategies that are capable of targeting the key effectors early while not inhibiting delayed repair. Early reports in a variety of disease states suggest that such pharmacologic strategies appear to have a favorable risk profile and offer substantial hope for patients.

Keywords: complement, vascular disorders, complement activation, cerebral blood flow, complement cascade, stroke therapy

\section{PUBLIC HEALTH IMPACT OF STROKE}

Worldwide, stroke is the second leading cause of death, and the third leading cause of disability-adjusted life-years (DALYs), with a staggering lifetime risk after age 25 of $26.5 \%(1,2)$. Even more concerning is the fact that the global incidence for both major stroke subtypes is increasing (37\% for ischemic and $47 \%$ for hemorrhagic over the last 20 years). Moreover, despite broad advances in general medical care, stroke-related deaths and DALYs have also increased by 26 and $19 \%$, respectively. It is also important to note that stroke is not merely a disease of the old and wealthy, as those living in low- and middle-income countries and those younger than 75 years of age make up the majority of victims.

\section{CURRENT TREATMENT OF ACUTE ISCHEMIC STROKE}

Since 1995, there have been a number of major advances in the prevention and treatment of stroke, most notably, the widespread advent of contemporary anti-platelet therapy, statin therapy, and the introduction of highly effective anti-hypertensive regimes (3). Particularly impactful has been the development of intravenous pharmacologic thrombolysis and intra-arterial mechanical thrombectomy following acute ischemic stroke (4). That said between 25 and 50\% of patients who are eligible for intravenous therapy within $9 \mathrm{~h}$ of stroke onset still suffer at least moderate disability 
(5-7). For those presenting with anterior circulation large vessel occlusions, substantial reperfusion is now achievable for $85 \%$ of patients, in some instances as late as $24 \mathrm{~h}$ after onset. Yet, $30-50 \%$ of patients eligible for this therapy are disabled as well, despite fairly small areas of core infarction $(8,9)$. Together, these data suggest that therapeutic targeting of post-reflow microvascular failure may have significant clinical utility for a substantial proportion of ischemic stroke patients.

\section{IMPORTANCE OF INFLAMMATORY MICROVASCULAR FAILURE ON STROKE OUTCOME}

While post-stroke inflammatory microvascular failure is governed by multiple biological cascades (10), our group long ago implicated the complement cascade as one of the central players that is potentially druggable (11). The first data suggesting that the complement cascade was involved in secondary tissue injury following re-perfused stroke dates to the late 1990s when we showed that soluble complement receptor 1 (sCR1), and its Sialyl-Lewis X glycosylated form (sCR1-sLex), which targeted complement inhibition to sites of activated endothelium, reduced ischemic tissue injury, improved outcome and penumbral blood flow (11). Nevertheless, 20 years of research has yet to result in the development of a clinically relevant anti-complement or even anti-inflammatory therapy for re-perfused stroke. Below we review the existing data implicating the complement cascade in cerebral ischemia reperfusion injury. We will not attempt to reiterate all that has been presented in two recent and exhaustive reviews $(12,13)$, but rather will attempt to present the data in a manner that facilitates clinical translation. In doing so, we will attempt to address the apparent inconsistencies in the data obtained from different model systems, as well as, the differences in the effect of acute and subacute treatment on cell death, cell survival and tissue regeneration.

\section{IN VITRO DATA EXAMINING THE ROLE OF COMPLEMENT IN CEREBRAL TISSUE HOMEOSTASIS AND ISCHEMIC INJURY}

Primary astrocyte, neuronal, and glial cell cultures express many of the complement cascade components (14). Together with resident microglia, these cells generally utilize the complement cascade to respond to infection. In addition, the complement cascade appears to be involved in both central nervous system development and tissue repair, in part by directing synaptic pruning and plasticity (15). Specifically, C1q and C3 tag weaker synapses for microglial removal and $\mathrm{C} 3 \mathrm{a}$ and $\mathrm{C} 5 \mathrm{a}$ and their receptors appear to be involved in cerebellar development (16, 17). C3a has also been shown to be involved in neuronal differentiation and maturation of neural progenitor cells (NPCs). It additionally guides migration of NPCs using an ERK 1/2 signaling pathway (18) and protects astrocytes from ischemiainduced cell death (19). C5a has also been shown to make microglia more resistant during ischemia by limiting the toxic effects of glutamate (20). Both C3a and C5a appear to be protective in culture against NMDA- and Kainateinduced neurotoxicity, respectively $(21,22)$. C1q drives neuronal survival in primary cultures and sublytic MAC has a similarly positive effect on oligodendrocyte progenitor cell cultures (23, 24). Complement receptor 2 (CR2) via C3d binding may regulate hippocampal neurogenesis in the adult rodent dentate nucleus (25).

Simulated ischemia via oxygen glucose deprivation (OGD) induces the production of neuronal $\mathrm{C} 1 \mathrm{q}$ and $\mathrm{C} 3$ which are associated with pro-apoptotic caspase-3 activation (26). Inhibiting C3 expression via siRNA enhances cultured neuronal viability (27). Blocking C5a reduces ischemia-induced apoptosis in culture (28). These results were less dramatic in human neuronal cultures due to the high expression of complement modifying inhibitors CD59, CD46, and CD55 (29).

Together the in vitro data suggests that in the absence of ischemic stress, components of the complement cascade are for the most part important to cell survival and appear to be potentially helpful in recovery of function after injury. By contrast, following ischemic stress, complement cascade activation appears to mediate apoptotic cell death, at least acutely.

\section{IN VIVO EXPERIMENTAL DATA EXAMINING THE ROLE OF COMPLEMENT IN CEREBRAL TISSUE INJURY AND REPAIR FOLLOWING ISCHEMIC INJURY}

\section{Initiation of Complement Activation Following Cerebral Ischemia Reperfusion}

It appears that ischemia-reperfusion results in the upregulation of the complement cascade in a number of ways. Recently, some data suggests that plasmin and thrombin released at the site of thromboembolism may play a role in complement activation independent of the classical, alternative, and lectin pathways (30-32). That said, more recent data in non-human primates suggests that this process is unlikely to be the source of most of the complement generated following cerebral ischemiareperfusion injury in the context of most reperfused human ischemic strokes (33). Therapeutic treatment with recombinant tissue plasminogen activator also is known to activate the complement cascade via a plasmin-mediated MBL-independent extrinsic/alternative pathway, but the degree to which this is relevant in clinical stroke is similarly unknown (34).

What is clear, however, is that, even in the absence of physiologic or therapeutic clot lysis, the ischemic endothelium expresses neo-epitopes, such as non-muscle myosin, annexin IV, and a subset of phospholipids that are recognized by circulating self-reactive IgM antibodies (35). Following ischemic injury, mannose-binding lectins (MBL) deposit on the activated endothelium. The antibody complexes activate the lectin pathway by reacting with MBL and the ficolins. Carbohydratebound MBL then cleaves $\mathrm{C} 2$ and $\mathrm{C} 4$, forming the $\mathrm{C} 4 \mathrm{~b} 2 \mathrm{a}$ (C3-convertase), which cleaves $\mathrm{C} 3$, and initiates the distal complement cascade (36). Preventing MBL function through genetic deletion or pharmacological manipulation is thought to be protective (37). Furthermore, even in the absence of 
thrombin or plasmin-mediated activation of the alternative pathway, amplification of this process appears to be driven by the alternative pathway. Efforts to block either this alternative pathway activation (38) or neo-epitope dependent complement activation (39) have proven extraordinarily effective in improving outcome in rodent models of cerebral ischemia-reperfusion injury (cIRI), as evidenced by reductions in infarct size, reduced apoptotic cell death, reduced neurological deficit scores throughout the recovery period, reduced gliosis, improved neurogenesis and angiogenesis even when employed $24 \mathrm{~h}$ postreperfusion, with the models including aged mice, female mice, and mice exposed to varying severities of ischemic injury (40).

Evidence that the classical pathway is not the primary initiator of complement cascade activation in focal cIRI, at least in adult animals, comes from the observation that $\mathrm{C} 1 \mathrm{q}$ deficient mice $\left(\mathrm{Clq}^{-/-}\right)$are not protected from cIRI and the $\mathrm{C} 1 \mathrm{q}$ that is initially expressed appears to be produced predominantly by microglia rather than neurons $(37,41,42)$. By contrast, $\mathrm{C} 1 \mathrm{q} / \mathrm{MBL}^{-/-}$, $\mathrm{MBL}^{-/-}$, and factor $\mathrm{H}^{-/-}$mice are all protected from focal cIRI, albeit to differing degrees depending on variations in the model system utilized $(43,44)$. Moreover, animals treated with a lectin pathway inhibitor, Polyman 2, or, as previously mentioned, an anti-MBL antibody are similarly protected as are those treated with CR2-fH, a targeted alternative pathway inhibitor $(44,45)$.

Despite the overwhelming amount of data implicating upstream initiation of the complement cascade by the alternative and lectin pathways, there are further data in an alternative model of cerebral ischemia that require mention. Neonatal mice subjected to a global ischemia reperfusion injury are protected by genetic deletion of C1q (46). In this model system, the severity of the ischemia is markedly less and the apoptotic burden is likely more significant than it is in focal stroke in adults (47). Given that this is dissimilar from what is seen in focal cIRI in adult animals including humans, and the fact that $\mathrm{Clq}$ deficiency may pre-dispose to epilepsy as a result of uncontrolled synaptogenesis, with post-stroke epilepsy worsening outcomes
(48), attempts at therapeutic manipulation in clinical cIRI should likely avoid strategies which include acute $\mathrm{C} 1 \mathrm{q}$ blockade. In fact, this hypothetical downside to early C1q blockade, may in part explain the failure of sCR1 treatment to improve cIRI in non-human primates (49).

\section{Downstream Mediators of Complement-Dependent Acute Tissue Injury Following Cerebral IRI}

Cleavage of C3 and generation of the anaphylatoxin (C3a), as well as the opsonins (iC3b, C3dg and C3d) and formation of $\mathrm{C} 5$ convertase (from $\mathrm{C} 3$ and $\mathrm{C} 3 \mathrm{~b}$ ), which in turn generates $\mathrm{C} 5 \mathrm{a}$ and $\mathrm{C} 5 \mathrm{~b}$ which aggregate with $\mathrm{C} 6, \mathrm{C} 7, \mathrm{C} 8$ and several C9s to form the MAC, could all potentially be involved in tissue injury following re-perfused stroke. However, most of the data suggest that, early following reperfusion, tissue injury is mediated principally by $\mathrm{C} 3 \mathrm{a}$ and to a lesser extent $\mathrm{C} 5 \mathrm{a}$ while MAC is not pathologically important, but rather, simply, a marker of complement cascade activation $(42,50,51)$. The first evidence of this was the finding that $\mathrm{C}^{-/-}$mice were markedly protected, while $\mathrm{C}^{-/-}$mice were not protected $(38,42)$. Similarly, C3aRA treatment early following stroke not only protected mice but enhanced delayed, post-stroke neurogenesis $(50,52) . \mathrm{C6}^{-/-}$mice were also not protected (44), and while $\mathrm{C} 5$ a receptor antagonist (C5aRA) (53) and C5 anti-body (54) treated mice were protected, the protection was more modest. These data together with the remarkably effective C3 site-directed therapy via CR2-Crry treatment (39), lead one to conclude that most complement mediated tissue injury following focal cIRI occurs as a result of $\mathrm{C} 3$ cleavage with the generation of $\mathrm{C} 3 \mathrm{a}$ and binding of the $\mathrm{C} 3 \mathrm{aR}$. $\mathrm{C} 5 \mathrm{a}$ binding of $\mathrm{C} 5 \mathrm{aR}$ likely plays a lesser but collaborative role.

\section{Complement Cascade in Cerebral Repair and Recovery}

While C3 depletion or blockade is protective in re-perfused stroke, especially when blockade is acute (52), germ-line depletion or chronic blockade results in loss of functional

TABLE 1 | The Role of the complement cascade in central nervous system cell clearance, viability, and cerebral tissue repair as well as in experimental cerebral ischemia reperfusion injury and human stroke.

\begin{tabular}{|c|c|c|c|c|c|}
\hline $\begin{array}{l}\text { Component of the } \\
\text { complement cascade }\end{array}$ & $\begin{array}{l}\text { Significant role in cell } \\
\text { clearance }\end{array}$ & $\begin{array}{l}\text { Significant role in } \\
\text { experimental inflammatory } \\
\text { microvascular no-reflow }\end{array}$ & $\begin{array}{l}\text { Significant role in } \\
\text { cerebral tissue repair }\end{array}$ & $\begin{array}{l}\text { Significant role in } \\
\text { cerebral cellular } \\
\text { viability in vitro }\end{array}$ & $\begin{array}{l}\text { Implicated in the } \\
\text { pathogenesis of } \\
\text { adult human stroke }\end{array}$ \\
\hline C1q (classical pathway) & Yes (15-16) & No (44-46) & Yes (27-9) & Yes (26) & No \\
\hline $\begin{array}{l}\text { Mannose binding lectin } \\
\text { (lectin pathway) }\end{array}$ & - & Yes $(39,45,47,49)$ & - & - & Yes $(70,72,74-6,78)$ \\
\hline $\begin{array}{l}\text { Factors D/B/H } \\
\text { (alternative pathway) }\end{array}$ & - & Yes $(40,41,43,48)$ & - & - & \\
\hline C3 & Yes (16) & Yes $(40,41,45)$ & Yes (23) & Yes $(30,36,74)$ & Yes $(66,69,84)$ \\
\hline C3a/C3aR & No & Yes $(54,56-7)$ & Yes $(57,64)$ & Yes $(17,21,24)$ & Yes (67) \\
\hline C3b & Yes & - & - & - & No \\
\hline CR1 & Yes & Yes (41) & - & - & No \\
\hline CR2 & - & - & Yes (28) & - & No \\
\hline C5 & - & Yes (63) & - & - & Yes (81) \\
\hline C5a/C5aR & No & Yes (62) & - & Yes $(22,25,31)$ & Yes (71) \\
\hline$c 5 b-9$ & Yes & No (48) & Maybe & Yes (27) & Yes (86) \\
\hline
\end{tabular}


protection at later time points as stroke recovery is impaired by decreased neurogenesis. This impairment of neurogenesis by complement blockade was most pronounced in models of experimental rodent stroke lacking reperfusion where even acute blockade is known to be ineffective (55). In an equally nonreperfused model, intranasal treatment of mice undergoing permanent photothrombotic stroke with $\mathrm{C} 3 \mathrm{a}$ in the late subacute period resulted in enhanced functional recovery (56). These data, together with the in vitro data presented above, strongly argue for limiting the clinical use of anti-complement therapeutics to the acute period during which reperfusion injury is most active (e.g., $<72 \mathrm{~h}$ post-reperfusion). Table 1 summarizes the current knowledge of different components of the complement cascade and their roles in the central nervous system, tissue repair, ischemia reperfusion injury, and human stroke.

\section{CLINICAL DATA FROM HUMANS SUFFERING STROKE SUGGESTING THAT MODIFICATION OF COMPLEMENT CASCADE ACTIVATION MIGHT IMPROVE OUTCOME}

\section{Evidence of Complement Cascade Activation in Human Ischemic Stroke and Association With Outcome}

Polymorphisms in C3, C5, and factor $\mathrm{H}$ are associated with an increased incidence of ischemic stroke as are higher plasma levels of C4 and C5 (57-60). Polymorphisms in MBL are associated with a better outcome after ischemic stroke $(43,61)$. In patients suffering a stroke, plasma levels of C3a, C3, C4, C5, C5a, factor B, MBL, MASP-1/2, and MAC are all elevated and ficolin-1, ficolin-2, and ficolin-3 reduced (62-66). Increased serum levels of C3, C3c, C4, and MBL are all associated with increased stroke severity, and patients who are MBL-sufficient have higher C3 plasma levels and suffer worse stroke outcomes $(43,67)$. Reduced early (within $6 \mathrm{~h}$ of onset) ficolin-1, a marker of activation of the lectin pathway, is independently associated with unfavorable outcome in adult human stroke (68). Moreover, postmortem studies have identified both complement and IgM deposition in the brain after stroke (69).

In addition, there is data in several other clinical scenarios of cerebral ischemia reperfusion injury where the complement cascade is activated. In cardiopulmonary bypass, glial injury is associated with complement cascade activation (70), and while anti-C5 monoclonal antibody therapy with a problematically long half-life did not improve overall cognition, it did improve outcomes in visuo-spatial functioning both acutely and at 1 month (71). Clinically relevant cerebral reperfusion injury is also experienced by a quarter of patients undergoing carotid endarterectomy for carotid stenosis (72). Interestingly MBL, $\mathrm{C} 3$, factor $\mathrm{H}$, and $\mathrm{C} 5$ polymorphism correlate with both early and late cognitive dysfunction, and C3a levels are not only increased in those injured, but also correlate with duration of cross-clamp (a surrogate of severity of ischemia), and are predicted by MBL polymorphisms (73-75). In patients with 
carotid stenosis, the degree of plaque burden, the severity of the stenosis and the instability of the plaque is correlated with elevated circulating levels of MAC and reduced circulating levels of ficolin-2 $(76,77)$. Finally, in comatose post-cardiac arrest patients, who suffer global cerebral ischemia reperfusion, C3a/C3 ratios independently predict survival (78).

\section{Evidence of Complement Cascade Activation in Hemorrhagic Stroke and Association With Outcome}

While less common than ischemic stroke, hemorrhagic stroke is associated with even worse outcomes and also exhibits complement cascade activation. This is important given that clinical efforts to revascularize ischemic stroke patients can result in either intracerebral or subarachnoid hemorrhage. In subarachnoid hemorrhage, C3a and M-ficolin levels are elevated in serum, cerebrospinal fluid and in the brain parenchyma and they are correlated with secondary ischemic injury and functional outcome (79-81). In patients suffering intracerebral hemorrhage, M-ficolin levels are similarly elevated and polymorphisms in factor $\mathrm{H}$ as well as iC3b levels are associated with functional outcome and mortality $(51,82)$. These observations support the experimental intracerebral hemorrhage data from rodents showing that inhibition of $\mathrm{C} 3 \mathrm{a}$ and $\mathrm{C} 5 \mathrm{a}$ receptors improve outcome with the effect at least in part due to amelioration of IL-1 dependent perihematomal edema formation $(83,84)$.

\section{Blood-Brain Barrier Dysruption Following Human Stroke and Its Implication for Systemic Intravascular Complement Blockade vs. Intracerebral Blockade}

There has been considerable speculation regarding the importance of the blood brain barrier in developing therapeutic strategies for central nervous system disease. Cerebral ischemia reperfusion injury differs from most of these other diseases in two important aspects. First, the blood brain barrier is opened to some degree following cIRI (85-87). Moreover, this opening is most profound in the time frame where anti-complement strategies are likely to prove most protective (39) prior to when regenerative and repair mechanisms appear most important. Secondly, it appears that even if anti-complement strategies fail to cross the blood brain barrier, much, if not most, of their beneficial effect is likely to be mediated intravascularly at the level of the cerebral arteriole and capillary. In this respect, anti-complement therapies are distinct from most traditional neuroprotective strategies aimed specifically at increasing the tolerance of neurons to ischemia and the downstream intracellular cascades that result. That said, even anti-complement therapies with large molecular sizes, such as Eculizumab, appear to be able to cross even a moderately impaired blood brain barrier in neuromyelitis optica and improve clinical outcome (88). This portends even better results for smaller anti-complement therapies.

\section{Complement Blockade in the Setting of Intravenous Thrombolytic Therapy}

The complement cascade has been implicated in cross-talk between the inflammatory cascade and the thrombotic cascade.
While in some settings complement inhibition has been shown to prolong bleeding times, the use of a variety of anti-complement therapies together with intravenous thrombolytic therapies in cIRI has consistently shown enhanced outcomes with no increase in bleeding and in some instances a reduction in hemorrhagic conversion, a complication of ischemic stroke, possibly due to stabilization of the blood brain barrier $(34,89)$. This is additionally important for use with pharmacologic thrombolytic therapies that can exacerbate hemorrhage and edema (34).

\section{Clinically Available Complement Cascade Modifying Therapies for Clinical Translation}

While it has widely been reported that anti-inflammatory strategies shown to be effective in experimental model systems fail to improve outcome following human stroke, most of this failure can be explained by the fact that these strategies are only useful in limiting reperfusion injury. Unfortunately, the patients included in these largely underpowered phase II trials do not have documented reperfusion and less than a third would even be expected to have a penumbra sufficient to demonstrate protection. Scientifically unjustified administration schedules based on incompletely studied pharmacokinetics has only further hindered efforts. Even so, despite all of these deficiencies, the most recent trials have shown some modest signal of benefit in both functional outcome and quality of life (90).

To date, anti-complement strategies have not been trialed in human stroke. Given the data presented above one would expect that either inhibition of the lectin and, or, alternative pathway might prove useful, as might inhibition of $\mathrm{C} 3$ convertase or the downstream anaphylatoxins, $\mathrm{C} 3 \mathrm{a}$ and $\mathrm{C} 5 \mathrm{a}$. While recombinant C1-INH is clinically available as Cinryze, Ruconest, and Berinert, an important, but fairly rare side effect is pro-thrombotic events which would be potentially disastrous in the setting of ischemic stroke $(91,92)$. While anti-C5 Eculizumab, is well-studied and has proven beneficial for a variety of diseases, both in and outside of the central nervous system, its inability to block C3a binding of $\mathrm{C} 3 \mathrm{aR}$ and its extremely long half-life $(>10$ d) makes its development less attractive. Selective alternative pathway inhibitors might also prove somewhat beneficial but the anti-C3 compstatin analogs seem to hold the most promise. Mechanistically, the latter block C3a and C5a generation, regardless of the upstream pathway responsible for activation of the cascade. They also appear to be safe in a variety of human diseases and have been designed with short half-lives that allow for ischemic protection without negatively impacting repair and recovery (93). The complement inhibitors currently in clinical development are listed in Table 2.

\section{AUTHOR CONTRIBUTIONS}

EC, AC, BC, AK, and JS contributed meaningfully and to the research and acquisition of data for this review, along with the subsequent analysis, drafting and revising of the paper. EC was the primary author due to his substantive drafting contributions, but all other authors provided equal contributions for the paper's creation. 


\section{REFERENCES}

1. Collaborators GBDLRoS, Feigin VL, Nguyen G, Cercy K, Johnson CO, Alam T, et al. Global, regional, and country-specific lifetime risks of stroke, 1990 and 2016. N Engl J Med. (2018) 379:2429-37. doi: 10.1056/NEJMoa1804492

2. Hankey GJ. The global and regional burden of stroke. Lancet Glob Health. (2013) 1:e239-40. doi: 10.1016/S2214-109X(13)70095-0

3. Sarikaya H, Ferro J, Arnold M. Stroke prevention-medical and lifestyle measures. Eur Neurol. (2015) 73:150-7. doi: 10.1159/000367652

4. National Institute of Neurological Disorders, Stroke rt-PA Stroke Study Group. Tissue plasminogen activator for acute ischemic stroke. N Engl J Med. (1995) 333:1581-7. doi: 10.1056/NEJM199512143332401

5. Thomalla G, Simonsen CZ, Boutitie F, Andersen G, Berthezene Y, Cheng B, et al. MRI-guided thrombolysis for stroke with unknown time of onset. $N$ Engl J Med. (2018) 379:611-22. doi: 10.1056/NEJMoa1804355

6. Campbell BCV, Mitchell PJ, Churilov L, Yassi N, Kleinig TJ, Dowling RJ, et al. Tenecteplase versus alteplase before thrombectomy for ischemic stroke. $N$ Engl J Med. (2018) 378:1573-82. doi: 10.1056/NEJMoa1716405

7. Ma H, Campbell BCV, Parsons MW, Churilov L, Levi CR, Hsu C, et al. Thrombolysis guided by perfusion imaging up to 9 hours after onset of stroke. N Engl J Med. (2019) 380:1795-803. doi: 10.1056/NEJMoa1813046

8. Goyal M, Menon BK, van Zwam WH, Dippel DW, Mitchell PJ, Demchuk AM, et al. Endovascular thrombectomy after large-vessel ischaemic stroke: a metaanalysis of individual patient data from five randomised trials. Lancet. (2016) 387:1723-31. doi: 10.1016/S0140-6736(16)00163-X

9. Turk AS III, Siddiqui A, Fifi JT, De Leacy RA, Fiorella DJ, Gu E, et al. Aspiration thrombectomy versus stent retriever thrombectomy as first-line approach for large vessel occlusion (COMPASS): a multicentre, randomised, open label, blinded outcome, non-inferiority trial. Lancet. (2019) 393:9981008. doi: 10.1016/S0140-6736(19)30297-1

10. Eltzschig HK, Eckle T. Ischemia and reperfusion-from mechanism to translation. Nat Med. (2011) 17:1391-401. doi: 10.1038/nm.2507

11. Huang J, Kim LJ, Mealey R, Marsh HC Jr, Zhang Y, Tenner AJ, et al. Neuronal protection in stroke by an sLex-glycosylated complement inhibitory protein. Science. (1999) 285:595-9. doi: 10.1126/science.285.5427.595

12. Ma Y, Liu Y, Zhang Z, Yang GY. Significance of complement system in ischemic stroke: a comprehensive review. Aging Dis. (2019) 10:429-62. doi: 10.14336/AD.2019.0119

13. Alawieh A, Elvington A, Tomlinson S. Complement in the homeostatic and ischemic brain. Front Immunol. (2015) 6:417. doi: 10.3389/fimmu.2015.00417

14. van Beek J, Elward K, Gasque P. Activation of complement in the central nervous system: roles in neurodegeneration and neuroprotection. Ann N Y Acad Sci. (2003) 992:56-71. doi: 10.1111/j.1749-6632.2003.tb03138.x

15. Stephan AH, Barres BA, Stevens B. The complement system: an unexpected role in synaptic pruning during development and disease. Annu Rev Neurosci. (2012) 35:369-89. doi: 10.1146/annurev-neuro-061010-113810

16. Chu Y, Jin X, Parada I, Pesic A, Stevens B, Barres B, et al. Enhanced synaptic connectivity and epilepsy in C1q knockout mice. Proc Natl Acad Sci USA. (2010) 107:7975-80. doi: 10.1073/pnas.0913449107

17. Benard M, Raoult E, Vaudry D, Leprince J, Falluel-Morel A, Gonzalez $\mathrm{BJ}$, et al. Role of complement anaphylatoxin receptors (C3aR, C5aR) in the development of the rat cerebellum. Mol Immunol. (2008) 45:3767-74. doi: 10.1016/j.molimm.2008.05.027

18. Shinjyo N, Ståhlberg A, Dragunow M, Pekny M, Pekna M. Complementderived anaphylatoxin C3a regulates in vitro differentiation and migration of neural progenitor cells. Stem Cells. (2009) 27:2824-32. doi: 10.1002/stem.225

19. Shinjyo N, de Pablo Y, Pekny M, Pekna M. Complement peptide C3a promotes astrocyte survival in response to ischemic stress. Mol Neurobiol. (2016) 53:3076-87. doi: 10.1007/s12035-015-9204-4

20. Persson M, Pekna M, Hansson E, Rönnbäck L. The complement-derived anaphylatoxin C5a increases microglial GLT-1 expression and glutamate uptake in a TNF- $\alpha$-independent manner. Eur J Neurosci. (2009) 29:267-74. doi: $10.1111 / \mathrm{j} .1460-9568.2008 .06575 . \mathrm{x}$

21. Osaka H, Mukherjee P, Aisen PS, Pasinetti GM. Complement-derived anaphylatoxin C5a protects against glutamate-mediated neurotoxicity. J Cell Biochem. (1999) 73:303-11.

22. van Beek J, Nicole O, Ali C, Ischenko A, MacKenzie ET, Buisson A, et al. Complement anaphylatoxin C3a is selectively protective against
NMDA-induced neuronal cell death. Neuroreport. (2001) 12:289-93. doi: 10.1097/00001756-200102120-00022

23. Cudrici C, Niculescu F, Jensen T, Zafranskaia E, Fosbrink M, Rus V, et al. C5b9 terminal complex protects oligodendrocytes from apoptotic cell death by inhibiting caspase-8 processing and up-regulating FLIP. J Immunol. (2006) 176:3173-80. doi: 10.4049/jimmunol.176.5.3173

24. Benoit ME, Tenner AJ. Complement protein C1q-mediated neuroprotection is correlated with regulation of neuronal gene and microRNA expression. $J$ Neurosci. (2011) 31:3459-69. doi: 10.1523/JNEUROSCI.3932-10.2011

25. Moriyama M, Fukuhara T, Britschgi M, He Y, Narasimhan R, Villeda S, et al. Complement receptor 2 is expressed in neural progenitor cells and regulates adult hippocampal neurogenesis. J Neurosci. (2011) 31:3981-9. doi: 10.1523/JNEUROSCI.3617-10.2011

26. Tohgi H, Utsugisawa K, Nagane Y. Hypoxia-induced expression of C1q, a subcomponent of the complement system, in cultured rat PC12 cells. Neurosci Lett. (2000) 291:151-4. doi: 10.1016/S0304-3940(00)01399-9

27. Yang J, Ahn HN, Chang M, Narasimhan P, Chan PH, Song YS. Complement component 3 inhibition by an antioxidant is neuroprotective after cerebral ischemia and reperfusion in mice. J Neurochem. (2013) 124:523-35. doi: 10.1111/jnc.12111

28. Pavlovski D, Thundyil J, Monk PN, Wetsel RA, Taylor SM, Woodruff TM. Generation of complement component C5a by ischemic neurons promotes neuronal apoptosis. FASEB J. (2012) 26:3680-90. doi: 10.1096/fj.11-202382

29. Pedersen ED, Froyland E, Kvissel AK, Pharo AM, Skalhegg BS, Rootwelt T, et al. Expression of complement regulators and receptors on human NT2-N neurons-effect of hypoxia and reoxygenation. Mol Immunol. (2007) 44:245968. doi: 10.1016/j.molimm.2006.10.022

30. Foley JH, Walton BL, Aleman MM, O'Byrne AM, Lei V, Harrasser M, et al. Complement activation in arterial and venous thrombosis is mediated by plasmin. EBio Med. (2016) 5:175-82. doi: 10.1016/j.ebiom.2016.02.011

31. Huber-Lang M, Sarma JV, Zetoune FS, Rittirsch D, Neff TA, McGuire SR, et al. Generation of C5a in the absence of C3: a new complement activation pathway. Nat Med. (2006) 12:682-7. doi: 10.1038/nm1419

32. Krisinger MJ, Goebeler V, Lu Z, Meixner SC, Myles T, Pryzdial EL, et al. Thrombin generates previously unidentified C5 products that support the terminal complement activation pathway. Blood. (2012) 120:1717-25. doi: 10.1182/blood-2012-02-412080

33. Keshari RS, Silasi R, Lupu C, Taylor FB Jr, Lupu F. In vivo-generated thrombin and plasmin do not activate the complement system in baboons. Blood. (2017) 130:2678-81. doi: 10.1182/blood-2017-06-788216

34. Zhao XJ, Larkin TM, Lauver MA, Ahmad S, Ducruet AF. Tissue plasminogen activator mediates deleterious complement cascade activation in stroke. PLoS ONE. (2017) 12:e0180822. doi: 10.1371/journal.pone.0180822

35. Elvington A, Atkinson C, Kulik L, Zhu H, Yu J, Kindy MS, et al. Pathogenic natural antibodies propagate cerebral injury following ischemic stroke in mice. J Immunol. (2012) 188:1460-8. doi: 10.4049/jimmunol.1102132

36. Ricklin D, Hajishengallis G, Yang K, Lambris JD. Complement: a key system for immune surveillance and homeostasis. Nat Immunol. (2010) 11:785-97. doi: $10.1038 /$ ni. 1923

37. De Simoni MG, Rossi E, Storini C, Pizzimenti S, Echart C, Bergamaschini L. The powerful neuroprotective action of C1-inhibitor on brain ischemiareperfusion injury does not require C1q. Am J Pathol. (2004) 164:1857-63. doi: 10.1016/S0002-9440(10)63744-3

38. Alawieh A, Elvington A, Zhu H, Yu J, Kindy MS, Atkinson C, et al. Modulation of post-stroke degenerative and regenerative processes and subacute protection by site-targeted inhibition of the alternative pathway of complement. J Neuroinflamm. (2015) 12:247. doi: 10.1186/s12974-015-0464-8

39. Alawieh A, Langley EF, Tomlinson S. Targeted complement inhibition salvages stressed neurons and inhibits neuroinflammation after stroke in mice. Sci Transl Med. (2018) 10:eaao6459. doi: 10.1126/scitranslmed.aao6459

40. Alawieh A, Tomlinson S. Injury site-specific targeting of complement inhibitors for treating stroke. Immunol Rev. (2016) 274:270-80. doi: $10.1111 /$ imr. 12470

41. Mack WJ, Sughrue ME, Ducruet AF, Mocco J, Sosunov SA, Hassid BG, et al. Temporal pattern of $\mathrm{Clq}$ deposition after transient focal cerebral ischemia. $J$ Neurosci Res. (2006) 83:883-9. doi: 10.1002/jnr.20775

42. Mocco J, Mack WJ, Ducruet AF, Sosunov SA, Sughrue ME, Hassid $\mathrm{BG}$, et al. Complement component $\mathrm{C} 3$ mediates inflammatory 
injury following focal cerebral ischemia. Circ Res. (2006) 99:209-17. doi: 10.1161/01.RES.0000232544.90675.42

43. Cervera A, Planas AM, Justicia C, Urra X, Jensenius JC, Torres F, et al. Genetically-defined deficiency of mannose-binding lectin is associated with protection after experimental stroke in mice and outcome in human stroke. PLoS ONE. (2010) 5:e8433. doi: 10.1371/journal.pone.0008433

44. Elvington A, Atkinson C, Zhu H, Yu J, Takahashi K, Stahl GL, et al. The alternative complement pathway propagates inflammation and injury in murine ischemic stroke. J Immunol. (2012) 189:4640-7. doi: 10.4049/jimmunol.1201904

45. Orsini F, Villa P, Parrella S, Zangari R, Zanier ER, Gesuete R, et al. Targeting mannose-binding lectin confers long-lasting protection with a surprisingly wide therapeutic window in cerebral ischemia. Circulation. (2012) 126:148494. doi: 10.1161/CIRCULATIONAHA.112.103051

46. Ten VS, Sosunov SA, Mazer SP, Stark RI, Caspersen C, Sughrue $\mathrm{ME}$, et al. Clq-deficiency is neuroprotective against hypoxicischemic brain injury in neonatal mice. Stroke. (2005) 36:2244-50. doi: 10.1161/01.STR.0000182237.20807.d0

47. Ten VS, Yao J, Ratner V, Sosunov S, Fraser DA, Botto M, et al. Complement component clq mediates mitochondria-driven oxidative stress in neonatal hypoxic-ischemic brain injury. J Neurosci. (2010) 30:2077-87. doi: 10.1523/JNEUROSCI.5249-09.2010

48. Tanaka T, Ihara M. Post-stroke epilepsy. Neurochem Int. (2017) 107:219-28. doi: 10.1016/j.neuint.2017.02.002

49. Mocco J, Mack WJ, Ducruet AF, King RG, Sughrue ME, Coon AL, et al. Preclinical evaluation of the neuroprotective effect of soluble complement receptor type 1 in a nonhuman primate model of reperfused stroke. $J$ Neurosurg. (2006) 105:595-601. doi: 10.3171/jns.2006.105.4.595

50. Ducruet AF, Hassid BG, Mack WJ, Sosunov SA, Otten ML, Fusco DJ, et al. C3a receptor modulation of granulocyte infiltration after murine focal cerebral ischemia is reperfusion dependent. J Cereb Blood Flow Metab. (2008) 28:1048-58. doi: 10.1038/sj.jcbfm.9600608

51. Ducruet AF, Zacharia BE, Hickman ZL, Grobelny BT, Yeh ML, Sosunov SA, et al. The complement cascade as a therapeutic target in intracerebral hemorrhage. Exp Neurol. (2009) 219:398-403. doi: 10.1016/j.expneurol.2009.07.018

52. Ducruet AF, Zacharia BE, Sosunov SA, Gigante PR, Yeh ML, Gorski JW, et al. Complement inhibition promotes endogenous neurogenesis and sustained anti-inflammatory neuroprotection following reperfused stroke. PLOS ONE. (2012) 7:e38664. doi: 10.1371/journal.pone.0038664

53. Kim GH, Mocco J, Hahn DK, Kellner CP, Komotar RJ, Ducruet $\mathrm{AF}$, et al. Protective effect of $\mathrm{C} 5 \mathrm{a}$ receptor inhibition after murine reperfused stroke. Neurosurgery. (2008) 63:122-5. Discussion 5-6. doi: 10.1227/01.NEU.0000335079.70222.8D

54. Costa C, Zhao L, Shen Y, Su X, Hao L, Colgan SP, et al. Role of complement component C5 in cerebral ischemia/reperfusion injury. Brain Res. (2006) 1100:142-51. doi: 10.1016/j.brainres.2006.05.029

55. Rahpeymai Y, Hietala MA, Wilhelmsson U, Fotheringham A, Davies I, Nilsson AK, et al. Complement: a novel factor in basal and ischemiainduced neurogenesis. EMBO J. (2006) 25:1364-74. doi: 10.1038/sj.emboj. 7601004

56. Stokowska A, Atkins AL, Moran J, Pekny T, Bulmer L, Pascoe MC, et al. Complement peptide C3a stimulates neural plasticity after experimental brain ischaemia. Brain. (2017) 140:353-69. doi: 10.1093/brain/aww314

57. Greisenegger S, Zehetmayer S, Bauer P, Endler G, Ferrari J, Lang W, et al. Polymorphisms in inflammatory genes and the risk of ischemic stroke and transient ischemic attack: results of a multilocus genotyping assay. Clin Chem. (2009) 55:134-8. doi: 10.1373/clinchem.2008.112151

58. Olsson S, Stokowska A, Holmegaard L, Jood K, Blomstrand C, Pekna $\mathrm{M}$, et al. Genetic variation in complement component C3 shows association with ischaemic stroke. Eur J Neurol. (2011) 18:1272-4. doi: 10.1111/j.1468-1331.2011.03377.x

59. Stokowska A, Olsson S, Holmegaard L, Jood K, Blomstrand C, Jern C, et al. Plasma C3 and C3a Levels in cryptogenic and large-vessel disease stroke: associations with outcome. Cerebrovasc Dis. (2011) 32:114-22. doi: $10.1159 / 000328238$

60. Stokowska A, Olsson S, Holmegaard L, Jood K, Blomstrand C, Jern C, et al. Cardioembolic and small vessel disease stroke show differences in associations between systemic C3 levels and outcome. PLoS ONE. (2013) 8:e72133. doi: 10.1371/journal.pone.0072133

61. Osthoff M, Katan M, Fluri F, Schuetz P, Bingisser R, Kappos L, et al. Mannosebinding lectin deficiency is associated with smaller infarction size and favorable outcome in ischemic stroke patients. PLoS ONE. (2011) 6:e21338. doi: 10.1371/journal.pone. 0021338

62. Mocco J, Wilson DA, Komotar RJ, Sughrue ME, Coates K, Sacco RL, et al. Alterations in plasma complement levels following human ischemic stroke. Neurosurgery. (2006) 59:1-6. doi: 10.1227/01.NEU.0000219221.14280.65

63. Tsakanova G, Stepanyan A, Nahapetyan K, Sim RB, Arakelyan A, Boyajyan A. Serine proteases of the complement lectin pathway and their genetic variations in ischaemic stroke. J Clin Pathol. (2018) 71:141-7. doi: 10.1136/jclinpath-2017-204403

64. Szeplaki G, Szegedi R, Hirschberg K, Gombos T, Varga L, Karadi I, et al. Strong complement activation after acute ischemic stroke is associated with unfavorable outcomes. Atherosclerosis. (2009) 204:315-20. doi: 10.1016/j.atherosclerosis.2008.07.044

65. Fust G, Munthe-Fog L, Illes Z, Szeplaki G, Molnar T, Pusch G, et al. Low ficolin-3 levels in early follow-up serum samples are associated with the severity and unfavorable outcome of acute ischemic stroke. J Neuroinflamm. (2011) 8:185. doi: 10.1186/1742-2094-8-185

66. Cojocaru IM, Cojocaru M, Tanasescu R, Burcin C, Atanasiu AN, Petrescu AM, et al. Changes in plasma levels of complement in patients with acute ischemic stroke. Rom J Intern Med. (2008) 46:77-80.

67. Zhang ZG, Wang C, Wang J, Zhang Z, Yang YL, Gao L, et al. Prognostic value of mannose-binding lectin: 90-day outcome in patients with acute ischemic stroke. Mol Neurobiol. (2015) 51:230-9. doi: 10.1007/s12035-014-8682-0

68. Zangari R, Zanier ER, Torgano G, Bersano A, Beretta S, Beghi E, et al. Early ficolin-1 is a sensitive prognostic marker for functional outcome in ischemic stroke. J Neuroinflamm. (2016) 13:16. doi: 10.1186/s12974-016-0481-2

69. Pedersen ED, Loberg EM, Vege E, Daha MR, Maehlen J, Mollnes TE. In situ deposition of complement in human acute brain ischaemia. Scand J Immunol. (2009) 69:555-62. doi: 10.1111/j.1365-3083.2009.02253.x

70. Baufreton C, Allain P, Chevailler A, Etcharry-Bouyx F, Corbeau JJ, Legall D, et al. Brain injury and neuropsychological outcome after coronary artery surgery are affected by complement activation. Ann Thorac Surg. (2005) 79:1597-605. doi: 10.1016/j.athoracsur.2004.08.061

71. Mathew JP, Shernan SK, White WD, Fitch JC, Chen JC, Bell L, et al. Preliminary report of the effects of complement suppression with pexelizumab on neurocognitive decline after coronary artery bypass graft surgery. Stroke. (2004) 35:2335-9. doi: 10.1161/01.STR.0000141938.00524.83

72. Heyer EJ, Adams DC, Solomon RA, Todd GJ, Quest DO, McMahon DJ, et al. Neuropsychometric changes in patients after carotid endarterectomy. Stroke. (1998) 29:1110-5. doi: 10.1161/01.STR.29.6.1110

73. Heyer EJ, Kellner CP, Malone HR, Bruce SS, Mergeche JL, Ward JT, et al. Complement polymorphisms and cognitive dysfunction after carotid endarterectomy. J Neurosurg. (2013) 119:648-54. doi: 10.3171/2013.4.JNS1368

74. Gigante PR, Kotchetkov IS, Kellner CP, Haque R, Ducruet AF, Hwang BY, et al. Polymorphisms in complement component $3(\mathrm{C} 3 \mathrm{~F})$ and complement factor $\mathrm{H}(\mathrm{Y} 402 \mathrm{H})$ increase the risk of postoperative neurocognitive dysfunction following carotid endarterectomy. J Neurol Neurosurg Psychiatry. (2011) 82:247-53. doi: 10.1136/jnnp.2010.211144

75. Szeplaki G, Hirschberg K, Gombos T, Varga L, Prohaszka Z, Dosa E, et al. Early complement activation follows eversion carotid endarterectomy and correlates with the time of clamping of the carotid artery. Mol Immunol. (2008) 45:3289-94. doi: 10.1016/j.molimm.2008.02.011

76. Si W, He P, Wang Y, Fu Y, Li X, Lin X, et al. Complement complex C5b-9 levels are Associated with the clinical outcomes of acute ischemic stroke and carotid plaque stability. Transl Stroke Res. (2018) 10:279-86. doi: 10.1007/s12975-018-0658-3

77. Fumagalli S, Perego C, Zangari R, De Blasio D, Oggioni M, De Nigris F, et al. Lectin pathway of complement activation is associated with vulnerability of atherosclerotic plaques. Front Immunol. (2017) 8:288. doi: 10.3389/fimmu.2017.00288

78. Jenei ZM, Zima E, Csuka D, Munthe-Fog L, Hein E, Szeplaki G, et al. Complement activation and its prognostic role in post-cardiac arrest patients. Scand J Immunol. (2014) 79:404-9. doi: 10.1111/sji.12167 
79. Mack WJ, Ducruet AF, Hickman ZL, Garrett MC, Albert EJ, Kellner $\mathrm{CP}$, et al. Early plasma complement C3a levels correlate with functional outcome after aneurysmal subarachnoid hemorrhage. Neurosurgery. (2007) 61:255-60. Discussion 60-1. doi: 10.1227/01.NEU.0000255518. $96837.8 \mathrm{E}$

80. Kasuya H, Shimizu T. Activated complement components C3a and $\mathrm{C} 4 \mathrm{a}$ in cerebrospinal fluid and plasma following subarachnoid hemorrhage. J Neurosurg. (1989) 71(5 Pt 1):741-6. doi: 10.3171/jns.1989.71. 5.0741

81. Llull L, Thiel S, Amaro S, Cervera A, Planas AM, Chamorro A. Ficolin1 levels in patients developing vasospasm and cerebral ischemia after spontaneous subarachnoid hemorrhage. Mol Neurobiol. (2017) 54:6572-80. doi: 10.1007/s12035-016-0180-0

82. Appelboom G, Piazza M, Hwang BY, Bruce S, Smith S, Bratt A, et al. Complement factor $\mathrm{H} \mathrm{Y402H} \mathrm{polymorphism} \mathrm{is} \mathrm{associated} \mathrm{with} \mathrm{an} \mathrm{increased}$ risk of mortality after intracerebral hemorrhage. J Clin Neurosci. (2011) 18:1439-43. doi: 10.1016/j.jocn.2011.04.001

83. Rynkowski MA, Kim GH, Garrett MC, Zacharia BE, Otten ML, Sosunov SA, et al. C3a receptor antagonist attenuates brain injury after intracerebral hemorrhage. J Cereb Blood Flow Metab. (2009) 29:98-107. doi: $10.1038 /$ jcbfm.2008.95

84. Garrett MC, Otten ML, Starke RM, Komotar RJ, Magotti P, Lambris JD, et al. Synergistic neuroprotective effects of $\mathrm{C} 3 \mathrm{a}$ and $\mathrm{C} 5 \mathrm{a}$ receptor blockade following intracerebral hemorrhage. Brain Res. (2009) 1298:171-7. doi: 10.1016/j.brainres.2009.04.047

85. Kassner A, Roberts TP, Moran B, Silver FL, Mikulis DJ. Recombinant tissue plasminogen activator increases blood-brain barrier disruption in acute ischemic stroke: an MR imaging permeability study. AJNR Am J Neuroradiol. (2009) 30:1864-9. doi: 10.3174/ajnr.A1774

86. Kassner A, Merali Z. Assessment of blood-brain barrier disruption in stroke. Stroke. (2015) 46:3310-5. doi: 10.1161/STROKEAHA.115.008861

87. Merali Z, Huang K, Mikulis D, Silver F, Kassner A. Evolution of blood-brain-barrier permeability after acute ischemic stroke. PLoS ONE. (2017) 12:e0171558. doi: 10.1371/journal.pone. 0171558
88. Pittock SJ, Berthele A, Fujihara K, Kim HJ, Levy M, Palace J, et al. Eculizumab in Aquaporin-4-positive neuromyelitis optica spectrum disorder. $\mathrm{N} \mathrm{Engl} \mathrm{J}$ Med. (2019). doi: 10.1056/NEJMoa1900866. [Epub ahead of print].

89. Alawieh A, Andersen M, Adkins DL, Tomlinson S. Acute complement inhibition potentiates neurorehabilitation and enhances tPA-mediated neuroprotection. J Neurosci. (2018) 38:6527-45. doi: 10.1523/JNEUROSCI.0111-18.2018

90. Elkins J, Veltkamp R, Montaner J, Johnston SC, Singhal AB, Becker K, et al. Safety and efficacy of natalizumab in patients with acute ischaemic stroke (ACTION): a randomised, placebo-controlled, double-blind phase 2 trial. Lancet Neurol. (2017) 16:217-26. doi: 10.1016/S1474-4422(16)30357-X

91. Morgan BP, Harris CL. Complement, a target for therapy in inflammatory and degenerative diseases. Nat Rev Drug Discov. (2015) 14:857-77. doi: $10.1038 / \mathrm{nrd} 4657$

92. Crowther M, Bauer KA, Kaplan AP. The thrombogenicity of C1 esterase inhibitor (human): review of the evidence. Allergy Asthma Proc. (2014) 35:444-53. doi: 10.2500/aap.2014.35.3799

93. Huang Y. Evolution of compstatin family as therapeutic complement inhibitors. Expert Opin Drug Discov. (2018) 13:435-44. doi: 10.1080/17460441.2018.1437139

94. Harris CL. Expanding horizons in complement drug discovery: challenges and emerging strategies. Sem Immunopathol. (2018) 40:125-40. doi: $10.1007 / \mathrm{s} 00281-017-0655-8$

Conflict of Interest Statement: The authors declare that the research was conducted in the absence of any commercial or financial relationships that could be construed as a potential conflict of interest.

Copyright (c) 2019 Clarke, Christophe, Khahera, Sim and Connolly. This is an openaccess article distributed under the terms of the Creative Commons Attribution License (CC BY). The use, distribution or reproduction in other forums is permitted, provided the original author(s) and the copyright owner(s) are credited and that the original publication in this journal is cited, in accordance with accepted academic practice. No use, distribution or reproduction is permitted which does not comply with these terms. 